\title{
Re-Writing the Myth of Draupadi in Pratibha Ray's Yajnaseni and Chitra Bannerjee Divakaruni's The Palace of Illusions
}

\author{
By Mohar Daschaudhuri
}

\begin{abstract}
All history, accounts of religion, social thought and philosophy reflect woman as the "other" even while speaking for her. Myth constitutes the elemental structures and patterns which shape the thought of a people. This paper explores how Pritabha Ray's novel Yajnaseni and Chitra Banerjee Divakaruni's The Palace of Illusions re-write the myth of Draupadi, the legendary wife of the five Pandava warriors in the epic Mahabharata. The two contemporary women writers from India recreate a protagonist who voices her opinions, musings, desires in a first person narrative from a woman's point of view. As upholder of Dharma, she is at once a player and a pawn in the patriarchal tale of jealousy and revenge. Yet, remaining within the bounds of Dharma, Draupadi, the protagonist in the novels, interrogates the symbolic values attributed to femininity, the meaning of duty, loss and death. Through a feminist re-reading the authors redefine the notion of Svadharma (an individual's duties) vis-à-vis the duties of a woman towards her husband and her society. The re-invented myth resists 'spousification' and deification of the woman, rendering her instead, a palpable character, vulnerable as well as independent. While Ray's character is in a search of a spiritual rebirth and relies on her inner deity, Krishna, for guidance all along the tortuous path of Dharma during her life and after her abandonment by her husbands, Divakaruni's heroine is a modern day adolescent, impetuous, intelligent and spontaneous. The two narratives may differ in their vision and style, yet, both these narratives succeed, in their unique way, to deconstruct the image of a deified ideal wife and to bring myth close to life.
\end{abstract}

Keywords: Epic, mythology, feminist rewriting, spousification, marginalized, Dharma

\section{Introduction}

The two novels which will be studied here, Pratibha Ray's Yajnaseni and Chitra Banerjee Divakaruni's The Palace of illusions, are both re-writings of the story of Draupadi, the enigmatic and powerful female protagonist of the epic Mahabharata. Krishna Dwaipayana Veda Vyasa is supposed to be the author of the Mahabharata though many critics point out the differences in style in the epic, revealing that later poets added certain verses and chapters in the course of time. The events which occur in the epic took place around 1000 B.C. (Karve 2008). The Mahabharata, the Ramayana and the Puranas are the oldest literature in Sanskrit and were transmitted orally from one generation to the next and were

\footnotetext{
*Assistant Professor, Department of Modern Languages, University of Calcutta, India.
} 
distinct from the Mantra (hymn) literature which consisted of philosophical and esoteric discourses.

The Mahabharata has been studied since the ancient times as a source for inspiration in every field of life: political, religious, social and cultural reformation. As Prof. Dandekar remarks, myths are an integral part of Indian culture and society: "If there is one single work which has proved to be of the greatest significance in the making of the life and thought of the Indian people and whose tradition continues to live even to this day and influence, in one way or another, the various aspects of Indian life, it is the Mahabharata" (Deshpande 2003, 199). This traditional value system needs to be reformulated in order to change the attitude of women towards themselves. Chitnis (2004) -an Indian feministobserves that, "the greatest obstacle to change in the direction of equality is the value system by which women abide. Women are conditioned to revere the father and to serve the husband as a devotee serves God" (Chitnis 2004, 20). In fact, the ideal of "pativrata" (husband-worshipper) idealized by the women of the Mahabharata too, such as Sita and Savitri have been romanticized in legends, folklores, and such ideals, entrenched in the Indian woman's psyche are difficult to transform unless as Chitnis suggests, the other qualities that these women possessed such as wit, intelligence, are newly asserted while re-writing their stories (Chitnis 2004, 21).

Women writers, in all regional languages in India, have been exploring myths. Deshpande (2000) -a feminist writer in Marathi and in English- discusses the importance of re-writing mythology by women writers as she realises, "that the basic problem is that not only myths have originated with men, their interpretation has also been in male hands" (Deshpande 2000, 87). Notable among recent fiction on mythological women are:

- Kunti and the Nishadini by Maheswata Devi, Doppadi by Maheswata Devi (short stories).

- Kavita Kane's Karna's Wife: The Outcaste Queen.

- Amish Tripathy's The Shiva Triology.

- Shashi Deshpande's The Stone Women.

- Priyanka Bhuyan's Chronicles of Kuru Woman.

- The Curse of Gandhari by Aditi Banerjee.

Devi $(1997,2005)$ draws a parallel between the women of the Mahabharata and marginalized subaltern tribal women victimized by the patriarchal attitude of the middlemen, the administrative overlords who, in the name of facilitating opportunities for the deprived classes, exploit them. "Daupadiin", the short story, reveal how tribal women who are doubly alienated as women and as out castes from the Brahminical society can become powerful voices against the entrenched patriarchy once they finally cease to uphold the notions of shame and dignity as defined by that patriarchy. Spivak (1998) says of its powerful heroine, "Dopdi is what Draupadi who is written into the patriarchal and authoritative sacred text of male power could not be" (Spivak 1998, 109). Amish Tripathy is a popular Indian English writer who fictionalizes the mythological stories which has nothing to do 
with women centric writing. More recent fiction by Aditi Bannerjee and Priyanka Bhuyan lack the depth and range of Pratibha Ray or Divakaruni. The two novels in this study have been chosen as they explore the figure of Draupadi who is very unlike Sita and most other mythological heroines such as Savitri, Ahalya or Kunti. Draupadi is distinct due to her "kanya" (virgin/ self-assertive) qualities. These two novels concentrate upon her individuality, wit and intelligence as well as her vocal protest against social laws and attitudes that berated women.

Ray's novel (1995) was translated from Oriya by Bhattacharya (1995) while Banerjee Divakaruni, who is an Indian writer living in the U.S.A., published her work in English (2008). Both are works of fiction recounted from the point of view of Draupadi, the marginalized feminine voice in a patriarchal society. The power to narrate the lives of women and to create a mythical past is thus undermined. Both writers project Draupadi as a symbol of retaliation, with the power to narrate myth and re-interpret the events which are recounted otherwise only from a masculine view point. Mythology if viewed as a symbolic capital which was dominated by the masculine voice is thus challenged and reshaped to revision an epic story from Draupadi's perspective.

This paper aims to undertake a comparative study of Banerjee Divakaruni's The Palace of Illusions and Ray's Yajnaseni in order to examine how the narratives deconstruct the idea of the ideal wife as the ancient text prescribed in the form of wifely Dharma and proposes an alternative reading where the woman regains her voice, her identity. At the same time, the two novels differ in their idea of Draupadi as a contemporary woman. They also differ in their treatment of the other characters and in their narrative strategies which again interrogate the idea of womanhood in conflicting feminist ideologies even within the context of Indian feminism.

\section{Existing Research in the Area}

Re-writing of the myth of Draupadi has been a constant endeavour by contemporary artists in theatre, dance and literature. Irawati Karve's book Yuganta published originally in Marathi in 1967 was translated into English in 1969. The book is a collection of scholarly essays based "...on the critical edition of the Mahabharata published by the Bhandarkar Oriental Research Institute" (Karve 2008, ix). As a meticulous scholar she delves into the various renditions of the Mahabharata in order to analyse the nuances of its various additions, omissions, re-interpretation in the course of time. Her essay on Draupadi (79-105) studies the character of Panchali in comparison with the character of Sita, heroine of the Ramayana. Unlike the two novels under analysis, Karve's scholarly article succinctly summarises the character of Draupadi, her dilemma, her desires and thus it renders clear the transgression or rather the innovations which have been introduced in the novels.

Other scholarly works on the Mahabharata include the work of Bhaduri (2014), which also includes the study of other women characters of the epic. 
Bhattacharya (2004) mentions Draupadi as one of the five virgins who are revered as powers of Prakriti but concentrates the discussion on the other virgins, Ahalya, Tara and Mandodari. His book, The Panchkanya of India's Epics dedicates two chapters to Draupadi comparing her to the other 'Panchkanya' and to mythical women from Western mythology such as Deidre as well as to women form Indian mythology such as Indrani as a vengeful woman. Citing example of her portrayal in the Bhil Bharath (a folk version of the epic), he shows how she has been traditionally associated with the seductive feminine figure possessing destructive qualities. Unlike the other heroines of the two epics, such as Sita or Savitri, Draupadi is associated with 'Shakti' (female power) in its destructive form (Bhattacharya 2017, 115-120).

In theatre, Saoli Mitra, for example, has questioned the conventional interpretations of the myths of Draupadi, Kunti from the Mahabharata in order to re-create in her plays, moments of women's assertion and a novel point of view from the perspective of the women in the Mahabharata. Mitra asserts: "We can suggest that there is a quest for truth in the literature that reflects the magic quality of an epic which resonates for people even today" (Mitra 2006, xiv). Suranjana Bhadra has analysed the transformative and metaphoric changes in the character of Kunti in Mitra's play Katha Amritasaman. According to Bhadra, "The stories of Draupadi, Kunti, Gandhari, Satyavati and others have been re-written to bring out their repressed desires, aspirations, hopes, dreams, complexities and dilemmas" (Bhadra 2016, 62).

The re-writing of the women characters in the epics, especially the character of Draupadi has become part of contemporary art, literature and dance in India. In an article, "Imaging Women: Resisting Boundaries of Gender in Women's Theatre in India" (Bhadra 2013), Bhadra explores the repressions of Draupadi, confined within the domestic roles of motherhood and housewifery with reference to Mitra's play who in turn was influenced by Irawati Kharve's Yuganta. Assamese danseuse Rita Devi in a solo dance drama has depicted the story of Draupadi as part of her performance of Panchkanya in a four hour performance in the Odiya Mahari devadasi style in Bombay in $1971^{1}$. In 1998, Kanak Rele, presented the story of Draupadi as Yuganta in Mohini Attam dance form interpreting in her own way, the stories of the five holy virgins showcasing the inner strength and courage of these epic characters which are still relevant for contemporary women in the modern era. In 1997, Hema Rajgopalan and her Natya Dance theatre staged Shakti Chakra, a Bharatnatyam dance performance depicting the life of Draupadi and Ahalya and this has been repeated a few times since then ${ }^{2}$.

The figure of Draupadi looms large as one of the 'Panchkanya' or Holy virgins (the others being, Ahalya, Kunti, Tara and Mandodari). While speaking of Draupadi, Upadhyaya (1993) refers to an ancient shloka or Sanskrit couplet, where she is referred to as a virgin lady whose invocation can annul sins which goes thus (Upadhyaya 1993, 138):

\footnotetext{
${ }^{1}$ http://www.enajori.com/?p=497.

${ }^{2}$ http://chicagopressrelease.com/news/chicagos-natya-dance-theatre-performs-shakti-chakra-theenergy-cycle-at-centre-east-sept-26.
} 
"Ahalyā Draupadi Kunti Tārā Mandodari tathā/

Pañcakanyāh smarenittyam mahāpātaka nāśaka// »

Or

"Ahalyā, Draupadi, Kunti, Tara and Mandodari,

The virgins five invoked ever destroy maha-sins"

(The above shloka is very current in popular culture but its origin is debated by scholars).

As Pradip Bhattacharya notes, the meaning of virgin here cannot be confused with the current meaning of the word used in our common vocabulary as all these women, "were tainted with affairs (all forced) with other men...Is it that if you are chaste on the inside no amount of forced relation can taint your purity?" (Bhattacharya 2017, 5). Anu Warrier is of the opinion that the 'Panchkanya' are those women who have been true to their independent nature, who are involved in sexual encounters with men who are not their husbands; the nature of the encounters is neither rape nor adultery (Bhattacharya 2001).

Draupadi has been one of the most assertive women in Indian mythology. According to Satya Chaitanya, Draupadi is at her most assertive self in the dice hall, where she has been brought by her husbands' rival, Dyurodhana and humiliated before her elderly father in law, the courtiers and princes (Chaitanya 2007). Yet despite the great humiliation of being dragged by her hair, wearing a single piece of cloth as was the custom in those days for menstruating women, she does not lose her calm and sarcastically reminds the elders of their duty towards their daughter-in-law, a princess and a wife of the famous five Pandavas. Incidentally this particular incident forms the crux of the Mahabharata as it is this humiliation which will propel the Pandavas and the Kauravas into the Great War. The two novels also depict this incident in detail.

Contemporary scholars study the nuances of Draupadi's body language and the silence which is provocative as well as her glances and gestures which initiate action from the part of Bhimsena, her third husband in the Dice scene (Bandopadhyay 2013).

For the purpose of this article, the primary works will consist of:

a) Yajnaseni, a novel by Pratibha Ray (Oriya, 1995, translated into English by Pradip Bhattacharya) in 1995 and

b) The Palace of Illusions, a novel by Chitra Banerjee Divakaruni written in English (2008)

A few articles have been published on the two novels separately but no comparative analysis exists of the two works. Secondly, the articles produced do not examine the treatment of Dharma in the re-writing of the character of Draupadi.

Bose (2010) has written on the women in the Mahabharata in her book Women in the Hindu Tradition: Rules, Roles and Exceptions, which is a significant compilation (with Sanskrit verse and their translation) of all the references to the goddesses such as Saraswati, Durga and Lakshmi as well as some women characters from the Vedas and the Puranas (Bose 2010). 
Among some recent critical articles on Pratibha Ray's Yajnaseni, Nanda (2018) studies the portrayal of Draupadi as a symbol of retaliation (Nanda 2018).

Divakaruni, who teaches and writes in the U.S.A., is more popular than Ray as she is an Indian English writer and therefore her body of work has been researched upon by students of English literature. Sowmya and Rebecca (2018) explore the novel from an inter-textual perspective as theorized by Julia Kristeva and finds the digressions Divakaruni has adopted from the main text in order to rewrite it from a feminist perspective. The authors rightly note: "The Palace of Illusions is the depiction of the magical world of the epic for its twenty-first century readers" (Sowmya and Rebecca 2018, 2). Ojha and Gorasya's (2019) short piece restricts itself to an analysis of the character of dhai-ma and though it claims to analyse feminist traits in the novel, it remains superficial and vague. Anantha (2019) puts forth the idea that Divakaruni has re-created the figure of Draupadi from the author's inner voice of conscience.

These articles do not make a comparative study of Ray and Divakaruni which are the only two novels based on the character of Draupadi written by Indian women writers in recent times. Draupadi being an exceptional mythological character, courageous to fight patriarchy yet herself a victim and a tenacious upholder of her polyandrous marriage, it becomes interesting to note that women writers interpret her 'feminism' in a myriad ways, reflecting the problems and issues which the writers themselves encounter in their respective time and social structure.

Secondly, this study will attempt to understand the 'differences' in ideological positions which have been debated by contemporary Indian feminists on the subject of re-writing of mythology, thus widening the scope of future research on the subject.

\section{Methodology}

\section{Mythology: Feminism in India and the West}

It is important to understand that though feminism in India was inspired by women's movements in the West, it has to be located within the broader framework of an unequal international world. Whereas in the West, the long and painful suffragette movements, struggle for equal pay for equal work, women's right to abortion and many such issues marked visible lines of inequality between the genders, in India, the concept of freedom and equality were alien to the hierarchical social system which subjugated not only women, but entire castes on the basis of lineage, learning, wealth (Chitnis 2004, 10-11). On the one hand the harshness and oppressiveness of all thee hierarchies was mitigated partially by a sense of mutuality, fixed behavioral codes, a philosophy of self-denial, and the emphasis which mythological women also portrayed - self-effacement of the ego for the good of the family and the society. With the rise of nationalism, women were portrayed as preservers of the inner sanctity of the home ('ghar') while the freedom fighters had to modernize the outer world ('bahir') in order to fight the 
colonial power. Mythological female-figures were upheld as ideals of the "pure" home-oriented feminine figure, whereas the image of the goddess "Bharat-mata" or Mother-India, provided the spiritual image of the motherland which had to be safeguarded from colonialist exploitation. She was a figure of strength, yet a maternal figure only. Chatterjee (2001) analyses how the dress and behavior of the middle class woman in Bengal had to undergo changes in order to emphasise her national identity, social emancipation as well as her spiritual purity (Chatterjee 2001, 130). "The new patriarchy", to quote Chatterjee, "...advocated by nationalism conferred upon women the honour of a new social responsibility, and by associating the task of female emancipation with the historical goal of sovereign nationhood, bound them to a new, and yet entirely legitimate, subordination" (Chatterjee 2001, 130). As Chatterjee elaborates, "this patriarchy combined coercive authority with the subtle force of persuasion...the adulation of the woman as goddess or as mother....It served to emphasize with all the force of mythological inspiration what had in any case become a dominant character of femininity in the new construct of 'woman' standing as a sign for 'nation,' namely, the spiritual qualities of self-sacrifice, benevolence, devotion, religiosity, and so on. This spirituality...the image of woman as goddess or mother served to erase her sexuality in the world outside the home." (Chatterjee 2001, 130-131).

\section{Comparative Methodology}

Our main concern will be to examine the new constructs which have been put in place by Ray and Divakaruni in the two novels, i.e., to examine whether the writers have challenged the idea of Draupadi as mother and wife and yet retained her character as a woman who has not transgressed 'dharma' or righteous path which she carves out for herself as a human being. Secondly, this comparative study should enable us to see the fine distinctions in her character which reflect the position and the style of the two writers, i.e. how have these women writers turned figures, plots, narratives, for different purposes, and to quote Tharu and Lalita, (40) "... what modes of resistance did they fashion? How did they avoid, question, play-off, re-write, transform, or even undermine..." the earlier images of the epic heroine in order to re-create a new woman?

The study will consist of:

I. Comparative analysis of the two novels from the thematic perspective of Draupadi and her self-assertion challenging the notion of Dharma through the following sub-divisions:

a. The epic period and the concept of Dharma in Hinduism.

b. Draupadi and her adherence to her Dharma as a woman (Stridharma) and the Dharma of her clan or tribe (Jati-Dharma).

c. Feminist interventions: interrogating the Father's Law.

d. Feminist interventions: against 'spousification'. 
II. Differentiating the narratives: Ray and Divakaruni

a) Feminisation and tradition.

b) Narrative strategies: voicing differences differently.

This article attempts to examine the principal themes and the strategies employed by Ray and Divakaruni to re-write the epic as a contemporary feminist narrative. At the same time, the two writers are distinct in their depiction of Draupadi as well as in their narrative style which will be examined in the concluding part of this study.

\section{Findings}

Pratibha Ray and Chitra Banerjee Divakaruni maintain the principal storyline of the Mahabharata and yet their feminist re-readings of the epic interrogate the role of the woman as a wife and as a human being. The heroines of the two novels are distinct from each other in their nature and their outlook on life yet both redefine the role of Draupadi as perceived in the popular imagination. They reenliven the epic, Ray portraying her protagonist with a sense of humour and sarcasm while Divakaruni's Draupadi is a modern woman who dreams her way into an illusory palace and enjoys every twist in her destiny which throws surprise at many turns of her life. Instead of being a victim of fate, both the novelists portray her as a mover of destiny, a woman wronged by her husbands, her elders and yet she is not silent. Her voice is made audible, for the first time, through the re-writing of the epic.

\section{Discussion}

\section{Comparative Analysis of the Novels}

The epic period and the concept of Dharma in Hinduism

Radhakrishnan (2008) states that the events related in the two epics, "occurred in the Vedic period, when the early Aryans poured in large numbers into the Gangetic valley and settled down, the Kurus round Delhi, the Panchalas near Kanauj....We have no evidence to show that the epics were compiled earlier than the $6^{\text {th }}$ century BC" (Radhakrishnan 2008, 223). The war of the Mahabharata takes place between the two Kuru clans, the Kauravas and the Pandavas where other kings such as the Panchalas (Draupadi's family) participate. The Ramayana and the Mahabharata were written around the period of this Aryan expansion. Radhakrishnan is of the opinion that the Ramayana deals with the wars of the Aryans with the then natives of India while the Mahabharata written by VedaVyasa who also compiled the Vedas, must have dated a little later approximately within a hundred years, "... when Vedic hymns had lost their original force and meaning and when ceremonial religion appealed to the people 
and caste grew into prominence. We may therefore put the beginning of the epic period somewhere during $6^{\text {th }}$ century before Christ, though changes were introduced into the epics to suit the conditions till the $2^{\text {nd }}$ century AD when they assumed their final form" (Radhakrishnan 2008, 243).

The Encyclopedia Britannica defines Dharma in Hinduism thus "[Dharma] is the religious and moral law governing individual conduct and is one of the four ends of life. In addition to the Dharma that applies to everyone, (Sadharana dharma) - consisting of truthfulness, non-injury and generosity, among other virtues, there is also a specific Dharma (Svadharma) to be followed according to one's class, status and station in life" 3 .

Svadharma, according to V. Jairam is the duty that arises from one's birth, profession, gender and caste affiliation ${ }^{4}$.

Gobrich Gupta (2000) explains the relevance of Dharma in the Hindu's life:

"Dharma enjoins each person to follow a set of social and religious duties appropriate to that person's individuality (sva-dharma) and social station that is usually in harmony with his or her religious or social duties (jati-dharma) as a member of a particular jati- that is natal community...A woman's dharma is designated as stri-dharma" (Gobrich Gupta 2000, 88).

Every Hindu has some idea of Dharma and there exists a social and a personal dharma. By the time of the Mahabharata, the notion of Dharma was quite entrenched in Hindu society. A woman could function only in the socially sanctioned dharmic way. As the mistress of the house she was the custodian of the family dharma; "she knows the rituals, teaches her children the basic dharma, and is thus responsible for the dharmic structure of the next generation (Gobrich Gupta 2000, 89)".

Draupadi and her adherence to her Dharma as a woman (Stridharma) and the Dharma of her clan or tribe (Jati-Dharma)

Sita and Draupadi are the two heroines of the two great Indian epics the Ramayana and the Mahabharata. Both are born of elements, Sita from earth and Draupadi from fire. This also makes them orphans and supernatural powers, beyond ordinary human origin. While King Janaka adopts Sita and her mother remains unmentioned in the epic, Draupadi appears to be a coveted daughter as she emerged out of her father's sacrificial offering to the Gods in order to avenge him. Her adopted father's wife, Prishati is mentioned in the epic. Moreover, Ray chooses the name Yajnaseni, which means the one born of fire, to name her novel. This is the only instance in the epics where a father renames himself from the daughter, as Draupadi's father is called Yajnasena after her birth (Karve 2008, 81).

While the entire Ramayana revolves around the greatness of King Rama, the ideal son, husband, brother and king, the Mahabharata has numerous heroes and Krishna the God himself appears to play an important role in it. While every Indian woman idealizes Sita, Draupadi remains an awed figure. She is neither a

\footnotetext{
${ }^{3}$ https://www.britannica.com/topic/dharma-religious-concept.

${ }^{4}$ https://www.hinduwebsite.com/hinduism/dharma.asp.
} 
goddess, nor a coveted human being despite the fact that she is courageous, learned, and wise. Yet, no Indian daughter is named after her for the fear that she might undergo the same fate as to marry five husbands and to be humiliated by the entire society during the infamous rape she had to undergo in the hands of Duryodhana, her family's enemy.

Needless to say, as the entire purpose of Draupadi's birth according to the Mahabharata was to avenge her father, her responsibility lay in being effective for that vengeance. Her father Drupad had been humiliated by his childhood friend, Drona when he had refused to acknowledge the latter as his equal. Drona, many years later had returned with his five young pupils, the Pandava brothers, adept at warfare to defeat the mighty army of Drupad. He succeeded and thus took possession of the better half of Drupad's kingdom, proving himself to be the king's equal. In order to teach a lesson to Drona, who was a mentor at the kingdom of Hastinapur, Drupad conducted a sacrificial offering inviting the best sages of the time in order to beget a worthy son who would avenge his honour. From the sacrificial fire, instead of a son, were born two children, Drhishtadyumna, a boy and Draupadi, a daughter. Both were pledged since their birth to the vengeance of Drupad's pride.

In both the novels this pupose of Draupadi's birth has been cited. Divakaruni's Draupadi even as a girl remains conscious that she and her brother are mere tools in the hands of their ambitious father. The young girl instigates the brother to revolt against the father. Ray's Draupadi knows her duty and remains committed to it, though she tries in vain to avoid the foreboding.

Feminist interventions: interrogating the father's law

Both the novels reveal the independent character of Draupadi which is itself a leap from the Hindu traditional way of thinking about a woman. Even goddesses, more powerful than the human female, are rarely seen as wielding power independently of any male counterpart. As Bose (2010) observes; "In traditional Indian society, even powerful goddesses are seldom imagined-just as mortal women are seldom imagined-as single, self-determined persons unattached to a male figure. In Hindu religious thought and practice, particularly in its evolved form, a goddess is always linked to a male figure as his mother or wife or daughter or sister, which suggests that her very identity rests on her relationship with males, with rare exception" (Bose 2010, 14). The duty of the wife is to follow the ideal of the goddesses, such as Sita, Lakhsmi and therefore to follow her husband in this life and even in her after-lives.

Since the very beginning of the novel, Ray's Yajnaseni reflects on her role and Dharma:

“...-my birth was not from my father's seed but from the sacrificial alter built for fulfilling a vow. From even before birth I was destined to avenge my father's insult! I was going to be a weapon for preserving Dharma on this earth and destroying the wicked. It was for this that I was born. Should only woman be forced to be the medium for preserving Dharma and annihilating 
evil throughout the ages? Is it woman who is the cause of creation and destruction?" (Ray 1995, 8)

Underneath the outward compliance of a docile Draupadi to the Dharma as laid down in the Hindu scriptures which demand that a woman should sacrifice her demands and wishes in order to obey the eldest male in the family, first her own father and brothers and then after her marriage, her husband, Ray points out the injustice suffered by Draupadi in clearer terms through the heorine's selfinterrogation at the time of her death which forms the introduction to the novel.

Ray's Yajnaseni rises above her personal wishes in order to uphold the family's honour or Dharma, time and again. Betrothed to Arjun, she faces a dilemma when a Brahmin youth appears to win the competition at her wedding ceremony and wins her hand. Her brother reminds her in the court:

"Not for Arjun but for the preservation of dharma has your birth taken place. It is to dharma you are offered.' ...Even if my dharma was destroyed, my father's dharma must be preserved" (Ray 1995, 46). Thus, Svadharma becomes secondary to pitr-dharma (father's honour). Once married, she is asked to walk barefoot by her husband Arjun who lives in the disguise of a mendicant. Being wife to a mendicant she must transform herself from a princess to a mendicant too. Draupadi happily accepts this part, and leaves behind her royal dresses, ornaments as according to her own confession, to follow her husband is her proper dharma (Ray 1995, 48).

Divakaruni's heroine is a girl who may be born in the times of yore but her expectations from life, her desires, her outlook of the world is that of a twentieth century girl. While in Ray, Draupadi is a cherished youngster full of admiration for her father, in Divakaruni, the father is a cold, haughty figure and Draupadi, even as a teenager despises his motives and his palace:

"I turned the resentment I couldn't express toward my father onto his palace" (Ray 1995, 6).

Feminist interventions: against 'spousification'

Altekar (1999) examines how the position of women deteriorated with time when it came in contact with other cultures. However, other critics disagree and it is from the time of the Upanishads and later during the age of the Epics that the role of women was restricted and primarily subordinated to patriarchal norms. Arya (2004) in her article examines the process of 'spousification' of Devi or Goddess and its negative ramification on female autonomy. Arya (2004) concludes that "...two distinct patterns emerge in this journey: One of the existence of an independent, almost feared entity, the independent Devi; and two, of the submissive role-playing ideal wife personification, what Lynn Gatwood (1985) calls the spouse-goddess" (Arya 2004, 37).

Draupadi's image is often conflated with the "spouse-goddesses", who, according to Leslie (1995) are subordinate to their husbands and therefore unthreatening (Leslie 1995, 320). In Ray and Divakaruni's re-interpretation of Draupadi, her terrible aspect of the essential woman is revealed as against the portrayal of the ideal wife in the most part of the Mahabharata. For example, 
though the epic recounts her marriage to the five Pandava brothers in an impersonal short verse, Ray and Divakaruni elaborate on the dilemma of the woman who had loved Arjun as her husband and who is subjugated to the law of the society to marry five husbands. Veda Vyasa is consulted as well as Krishna to resolve the dilemma. But both insist that it is necessary for her to string the Pandava brothers in one bond through a common marriage. Divakaruni's heroine is surprised by Vyasa's verdict, made her feel angry and helpless "my situation was very different from that of a man with several wives. Unlike him I had no choice as to whom I slept with, and when. Like a communal drinking cup, I would be passed from hand to hand whether I wanted it or not" (Banerjee Divakaruni $2012,120)$. Needless to say, such reflections voice the woman's misery which remained muted in patriarchal renderings of the epic, find a voice in this story.

Bose 2010 remarks, "In traditional Hindu society the obvious site for women to exercise any kind or degree of authority is the family, where again we may observe the ambivalence inherent in an individual's exercise of authority solely in the service of the group, often if not usually through self-sacrifice" (Bose 2010, 9). The right of women, in traditional Hindu society is subservient to the duties she must fulfill towards her tribe, her caste, her family and her husband. The authority she wields is dependent on her position in the family. As a mother she is revered while as a wife she must obey her elders. Both Ray and Divakaruni's Draupadi adheres to the norms yet they interrogate it and sometimes transgress their right. Draupadi is feared not just because of being a Sati (a perfect wife) but also for the fact that she had the intelligence and astute nature to free her five husbands, their weapons and their kingdom of Indraprastha (which Yudhishthira lost again the following day) when they had lost everything in the dice game, through the three boons granted to her by Dhristarashtra, the emperor of the Kauravas after her insulting rape at his court. Both Divakaruni and Ray elaborate on this episode of their life. At every important dilemma of life, Draupadi, unlike Sita, must face grave consequences for actions which are not of her doing, but a result of destiny. She is impetuous, haughty and therefore more human of the two heroines. It is her human weaknesses, her enforced subservience to the laws of an extremely patriarchal society and her wisdom to overcome them that reveal her ingenuity and vulnerability and bring her close to our hearts.

Yajnaseni in Ray's version, is human yet most courageous and challenges her husband's knowledge of Dharma when in spite of losing himself, her eldest husband Yudhisthira has the audacity to pledge his wife as prize for the dice game. She is menstruating, and is in one cloth when Dusshasana (her husbands' rival, the second eldest of the Kaurav brothers) drags her from the inner chambers to the palace hall, before a court filled with men who look at her with lustful eyes and enjoy her distress. Even the greatest of the elders, such as Bhishma who had vowed celibacy and had been granted eternal life, the emperor father, Dhritarashtra, Dronacharyya the sage and mentor of the entire Kuru clan, remain silent spectators of this disgraceful scene. Here too, transgressing her rights, Draupadi questions her elders whether the wise men of Aryavarta would endow this shameful act. Ray's feminist re-reading points out at the indiscrepancy of this act: "A mild murmur 
arose and died down. Would any woman dare to demand an explanation of her elders with such firmness?" (Ray 1995, 238).

The episode of Draupadi's rape is rendered in the Mahabharata but in Ray, Draupadi's reflections and her spiritual inclination, her total surrender to Krishna renders the incident humanist and philosophical: "Without total surrender of the self, God's compassion is not found. The moment this thought came to me, I forgot all shame, modesty, doubt. Leaving hold of that single cloth, I raised up both my hands. In anguish I cried, 'Lord, I am not mine own. This body is not mine. Therefore the whole responsibility of this body is yours. All is yours...It is you who are the primal cause. I know nothing" (Ray 1995, 243).

\section{Differentiating the Narratives: Ray and Divakaruni}

The Hindu tradition itself being full of contradictions in its definition of Dharma, the role of women as goddesses and human figures, the portrayal of Draupadi is bound to be distinctive in each rendition of her story. In this part, the distinctive nature of the two novels will be elaborated keeping in mind that the novels were penned at a difference of more than a decade (1995-2008), Ray's novel preceding that of Divakaruni by thirteen years.

Secondly, the reader must consider the fact that Ray was one of the women writers in India when the society in general was wary of feminist voices and that Ray's other novels depict the traditional society where women adhere to prevalent social norms and if they voice "differences" it is very subtly, remaining within the margins of what is permissible within social norms. Divakaruni's works are scripted in the diasporic context and envisage a foreign reader or readers who travel to many countries and are not bound by the social paradigms of the traditional Indian society.

\section{Feminisation and tradition}

As Bannerjee Divakaruni (2012) mentions in the "author's note", she was left unsatisfied with the part the women play in the epic, "somehow they (the women) remained shadowy figures, their thoughts and motives mysterious, their emotions portrayed only when they affected the lives of the male heroes, their roles ultimately subservient to those of their fathers or husbands, brothers or sons" (Bannerjee Divakaruni 2012, xiv). Re-writing of the epic was for Divakaruni, a way to give voice to the women, to "place the women in the forefront of the action...to uncover the story that lay invisible between the lines of the men's exploits." (Bannerjee Divakaruni 2012, xv). And thus it is that Divakaruni portrays the heroine of the Mahabharata, a reflection of a modern day girl and woman, retelling her story, "with all her joys and doubts, her struggles and her triumphs, her heartbreaks, her achievements, the unique female way in which she sees her world and her place in it....It is her life, her voice, her questions, and her vision that I invite you into in The Palace of Illusions" (Bannerjee Divakaruni 2012, xv). The notion of Svadharma or Dharma does not appear in the narrative except in a few instances. 
Draupadi's image as portrayed by Ray is not that of a woman whose merit lies in revolting against the fabric of the society itself, but being that princess who submitted herself to the laws of the ideal Hindu woman, within the very structure of the family, yet interrogated them.

Bannerjee Divakaruni's Draupadi is of more lighthearted character, appears less burdened by her dharma as daughter and wife. It is Vyasa (appearing in the role of a fortuneteller in this novel) who makes her aware of her impending fate: "You will marry the five greatest heroes of your time. You will be queen of queens, envied even by goddesses...You will be remembered for causing the greatest war of your time...Yes, indeed, you will leave a mark on history" (Bannerjee Divakaruni 2012, 39).

Unlike Ray's Yajnaseni who seems aware of her duties and of her destiny from the moment of her birth and is constantly reminded of the same by her mentor Krishna, Divakaruni's protagonist is childlike, enjoys her days of innocence and she appears saddened by mundane incidents in her father's palace, by the treatment of other step-sisters or by the cold stony look of the building. In fact the word Dharma, which appears thirty-eight times in the first fifty pages of Ray's novel, does not appear even once in Divakaruni in the same number of pages.

Not only is Divakaruni heroine unmindful of her duties, her eventful life but her mentors too, especially her elderly mother-like dhai-ma, do not seem to prepare her for her fate. She too is oblivious of her ward's destiny and behaves with her as with any little girl not even of the rank of a princess.

\section{Narrative strategies: voicing differences differently}

Lancer (1986) poses the feminist question vis-à-vis narratology, that most theories of the narrative have been based on "men's texts or texts treated as men's texts" (Lancer 1986, 676). Such writing therefore lacks the tools to differentiate the writings of women and to examine their specificity. She suggests a re-writing of narratology "...that takes into account the contributions of women as both producers and interpreters of texts" (Lancer 1986, 677). In this regard, the text of Ray and Divakaruni could be re-examined as unique works which have adopted strategies of re-writing the story of Draupadi with a specific feminist narrative strategy.

Both the novels are written from the perspective of Draupadi, in the first person and thus the voice of the heroine can be heard. History has been nuanced with personal beliefs, philosophy, hurt pride - thus humanizing the stiff structure of the third person epic narrative. Yet the novels differ in their style, their voice and structure. Yajnaseni's introductory chapter is a philosophical reflection on life, on the past where Draupadi, befallen at the path to heaven has been abandoned by her five husbands while her sons are far away ruling their kingdom at Hastinapur. Divakaruni's novel follows a fairy-tale chapterisation, each chapter being titled with a single noun, such as "fire", "cosmology", "blue" and the protagonist appears from the very beginning as a prisoner to her fate, a little girl trapped in a dark, stony and lonely fortress at Panchal. Various incidents, such as the appearance of a sorceress at her father's palace who teaches her the secrets to be a good queen, a 
good cook as well as to live the austere life of a mendicant -all of which will later enable her to live her days with the vagrant Pandavas- have been introduced by the author and do not exist in the main text. Such incidents as the predicaments by the Veda Vyasa who foretells her future, the gift of the parchment and a tale by the sorceress are elements which romanticize the story and don it with a fantastic fairy-tale atmosphere.

Ray introduces characters such as Nilambani, the princess' maid and Maya, a confidante, (a gift from Krishna's palace at Dwarka) in order to facilitate the narrative with these women as Draupadi's confidantes. However, unlike the sorceress, these characters are not new, but find their brief mention in the epic itself.

The principal events of the Mahabharata have been recounted in both the novels: the story of enmity between Drupad and Dronacharya which leads to the sacrificial fire and the birth of Draupadi, the marriage of Draupadi to the five Pandava brothers, Draupadi's molestation and rape at the dice game and the Great War. In Ray (1995), the voice of Draupadi is grave and wise even at its most personal moments: "At the very first sight of Karna, I do not know why, a fountain of maternal love gushed forth from my heart" (Ray 1995, 117), while the same incident of encountering the illegitimate son of Kunti, the handsome Karna is recounted differently by Divakaruni. On seeing the portrait of Karna Draupadi feels attracted by the solitude in his eyes: "His eyes were filled with an ancient sadness. They pulled me into them....Absurdly I wanted to be the reason for his smile" (Ray 1995, 69).

Ray's narrative is interspersed with philosophical musings, and the impersonal objectivity of the third person narration is more abundant in her narrative: "The inner being that is pervaded by Krishna is bereft of pride. Where pride rules, there only the shadow of Krishna resides, not Krishna....for getting rid of pride the ego has to be eliminated. One has to surrender. It is necessary to offer one self before others like the offerings made to a deity" (Ray 1995, 208). Thus Krishna remains a central character in Draupadi's life and musings. It is to him that Ray's Yajnaseni dedicates her life, her suffering and her freedom. It is for him alone that she lives. Ray's heroine is not an ordinary human being. From the very onset of the novel, the reader is aware of the towering feminine personality who not only shaped an epoch, but also shaped the spiritual destiny of a nation. Her life appears to be an adventure as well as an inner journey towards self-realisation.

\section{Conclusion}

Reinterpretations and re-writings of the myth of Draupadi exist in various oral and folk traditions, in India as well as in the Far-East. Poets, novelists in various Indian and foreign languages have re-told the story and comparative study of these stories would entail a separate research. This article has concentrated on two reappropriations of the story of Draupadi which are available in English and are contemporary in their production. 
Both the novels evolve around the story of the epic Mahabharata and redefine the idea of Draupadi being a woman like any other human being with her opinions, desires and expectations from life for which she had to challenge the notion of 'Stri-dharma' (woman's Dharma). While popular mythology and religion define Draupadi as the ideal wife, a suffering woman who obeyed first her father, her brother and then her husbands, these two novels endow her with a voice of her own, if not rebellious yet unrelenting in her questioning. The novels differ in their treatment and style.

Draupadi being a Kanya, or a virgin has been re-defined and emphasised upon by both Ray and Divakaruni. Here, as Chaturvadi (2008) explains in the context of Madhavi, another Kanya from the Mahabharata, "true virginity is of the mind and not of the body" (Chaturvadi $(2008,161)$. The relationship between Draupadi and Krishna who acts as an intelligent advisor as well as intimate confidante who guides Draupadi, depicted in the two novels, establish the independence of thought and action on the part of the protagonist. Such positive construction of femininity contest and displace the more prevalent models of female meekness, subordination and obedience (in the form of 'pativrata' or husband-worshipper) derived from other mythological figures such as Sita, Savitri and Anasuya.

While Ray's Yajnaseni is a regal, wise and patient queen, engaged in a spiritual quest, Krishna being her ultimate friend and master to whom she dedicates her desires and her calumny, Divakaruni portrays a spirited young, impatient and yet strong woman who is perhaps beleaguered by fate, but who has the tenacity to persist in her own path of liberation from a society which misunderstood her. The narrative structure and tone of Yajnaseni is serious, grave, the story going to and fro the present and the past, thus allowing self-reflection and philosophical afterthoughts to its subject-narrator. Divakaruni has modeled her novel in a quasi chronological manner interspersed with stories recounted by other voices, such as the dhai-ma, or Krishna who substantiate the narrative with stories of the past, and forebodings of the future. The novel abounds in dialogic conversations while Ray's work is replete with reflective monologues.

Sunder Rajan (2004) explains that, "In contrast to the Judeo-Christian tradition, Vedic Hinduism had female deities and (arguably) a matriarchal worldview (and that)...their dissemination via popular cultural forms like folk-theatre, mythology, song-and-dance performances and cinema has assisted the rise and dominance of women political leaders like Indira Gandhi, or folk heroines such as Phoolan Devi..." (Sunder Rajan 2004, 320-321). While such depictions may replace the world-view that women are universally exploited in Indian society, this may also lead to the temptation of idealising non-western societies as a 'resource' to meet the inadequacies of western philosophies and life-styles. Secondly, she points out that mythological figures drawn from Hindu, Brahminical texts may draw support from Hindu nationalist rhetoric and become propangandist in nature which will alienate non-Hindu and lower caste women (Sunder Rajan 2004, 324). Similarly, Spivak (1985) alerts us that in their resistance to the imperialist effacement of the mother-goddess figure, nationalist (male) elites were also performing a "reverse-ethnocentrism" (Spivak 1985, 125). 
The re-construction of the figure of Draupadi, as the powerful, decisive, sometimes vociferous and revengeful woman with a mind and direction of her own may be construed in various political avatars as has been pointed out by contemporary feminists. The danger of idealizing an upper-caste Hindu woman may suit ideologies which may diminish the liberal character of feminism. Yet, in order to desist from such politicization, it should not be neglected that a large part of India's and even South-Asia's population can relate themselves to these figures. Secondly, re-writing the story of Draupadi is only a step to 'recover' the spaces of women's autonomy which Indian Vedic and post-Vedic society allowed and upheld but was gradually lost in time. Ray and Divakaruni have endowed the character with a new life, one quite different from the other, yet with a unique selfimage, and an 'agency' which may go a long way in positing an example of an articulate, determined and self-righteous woman from Indian mythology.

\section{References}

Altekar AS (1999) The position of women in Hindu civilization. New Delhi: Motilal Banarsidass.

Anantha S Voice of conscience in Chitra Banerjee Divakaruni's the palace of illusions. International Journal of English language, Literature in Humanities (IJELLH) 7(9): $570-581$.

Arya A (2004) Devi: the disempowered goddess. In R Bhattacharya (Ed), 35-49. Behind Closed Doors: Domestic Violence in India. New Delhi: Sage.

Bandopadhya I (2013) Mahabharata: Draupadi, body language, eyes, and Vyasa's poetry. Retrieved from: https://bit.ly/3cAwXgA. [Accessed 30 April 2020].

Bannerjee Divakaruni C (2012) The palace of illusions. New York: Doubleday.

Bhadra S (2013) Imaging women: resisting boundaries of gender in women's theatre in India. The Criterion 4(2): 1-10.

Bhadra S (2016) Retelling the myth of Kunti: Saoli Mitra's timeless tales. Postscriptum: An Interdisciplinary Journal of Literary Studies 1 (2): 61-69.

Bhaduri N (2014) Krishnā, Kunti ebong Kaunteya (Bengali). Kolkata: Ananda Publishers.

Bhattacharya P (2001) Panchkanya: women of substance. Retrieved from: https://bit.ly/ 2Lv8EVe. [Accessed 30 April 2020].

Bhattacharya P (2004) Five holy virgins, five sacred myths. Manushi (Mar-Apr): 4-11.

Bhattacharya P (2017) The Panchkanya of India's epics. Chennai: Sri Visnu Mohan Foundation.

Bose M (2010) Women in the Hindu tradition, rules, roles and exceptions. New York: Routledge Hindu Series, Routledge.

Chaitanya S (2007) The silencing of Draupadi. Retrieved from: https://bit.ly/2LoBEy4. [Accessed 30 April 2020].

Chatterjee P (2001) The Nation and its fragments. New Delhi: OUP.

Chaturvedi B (2008) The Women of the Mahabharata- the question of truth. Hyderabad: Orient Longman.

Chitnis S (2004) Feminism: Indian ethos and Indian convictions. In M Chaudhuri (Ed), 825. Feminism in India -2: Issues in Contemporary Indian Feminism. New Delhi: Kali for Women.

Deshpande S (2000) The stone women. Kolkata: Writer's Workshop. 
Deshpande S (2003) A toppling world view: writing from the margin and other essays. India: Penguin Books.

Devi M (1997) Breast stories. Translated by GC Spivak. Kolkata: Seagull Books.

Devi M (2005) After Kurukshetra. Translated by A Katyal. Kolkata: Seagull Books.

Gobrich Gupta S (2000) The goddess, women and their rituals in the Hinduism". In M Bose (Ed), 87-106. Faces of the Feminine in Ancient, Medieval and Modern India. New Delhi: OUP.

Karve I (2008). Yuganta: the end of an epoch. Hyderabad: Orient Blackswan.

Lancer S (1986) Toward a feminist narratology. In RR Warhol, D Price Herndl (Eds), Feminisms: An Anthology of Literary Theory and Criticism. Rutgers University Press.

Leslie J (1995) The perfect wife: the Stridharmapaddhati of Tryambakayajvan. Translated by J Leslie. New Delhi: OUP Penguin Books.

Mitra S (2006) Five lords, yet none a protector and timeless tales: two plays. Translated by R Datta, I Chanda, M Bhowmik. Kolkata: Stree.

Nanda S (2018) Revolting gender in Pratibha Ray's Yagnaseni and Mahashweta Devi's Draupadi. The International Journal of English and Literature 8(6): 87-90.

Ojha M, Gorasya LS The palace of illusions: a feminist critique. International Journal of Research and Analytical Reviews 6(2): 2349-5138.

Radhakrishnan S (2008) Indian philosophy. New Delhi: OUP.

Ray P (1995) Yajnaseni, the story of Draupadi. Translated by P Bhattacharya. New Delhi: Rupa \& Co.

Sowmya T, Rebecca CS (2018) A reading of Divakaruni's the palace of illusions. MuseIndia 78(Mar-Apr).

Spivak GC (1985) Can the Subaltern speak? speculation on widow sacrifice. Wedge 7/8(Winter/Spring): 120-130.

Spivak GC (1998) In other worlds: essays in cultural politics. London: Routledge.

Sunder-Rajan R (2004) Is the Hindu goddess a feminist? In M Chaudhuri (Ed), 318-333. Feminism in India -2: Issues in Contemporary Indian Feminism. New Delhi: Kali for Women.

Upadhyaya KD (1993) Some characters of the Mahabharata as depicted in folk traditions of Eastern India. In KS Singh (Ed), Mahabharata in the Tribal and Folk Traditions of India. Shimla: Indian Institute of Advanced Study. 